\title{
INDIAN ASTRONOMY IN ANCIENT CHINA
}

\author{
JIANG XIAO-YUAN \\ Shanghai Observatory, Academia Sinica, 80 Nandan Rd, Shanghai 200030, China \\ Nanjing
}

Indian astronomy was introduced into China along with the intrusion of Buddhism. This process lasted about one thousand years in the Mediaeval age. For the study of this process, there are a lot of materials in ancient Chinese historic texts, while the Buddhist scriptures in Chinese translation are very important first-hand materials.

At first, we inspected six questions as follows:

1. Early contents

- Cosmic model

- Booklists of Indian astrology that come to China.

2. Three well-known Indian astrological families in the 7th-8th centuries' China (Tang Dynasty)

- Kasyapa

- Kumara

- Gautama

3. Navagraha Calendar (Jiuzhi Calendar, 718 AD) and its origin

Navagraha Calendar was translated and edited by Qutan Xida. Its source texts are known at least Pancasidhantika (about $550 \mathrm{AD}$ ) of Varahamihira, and probably also Khandakhadyaka (665 AD) of Brahmagupta. All of these texts have their Greek headspring, so there are still a lot of Greek astronomical compositions in Navagraha Calendar.

\section{Skill of Futian}

Skill of Futian is a branch of Indian horoscope astrology. It was in vogue in China for several hundred years.

\section{Yusi Sutra}

Yusi Sutra is another branch of Indian horoscope astrology. It was also in vogue in the Mediaeval China.

\section{Portraits of star-gods}

Portraits of star-gods were very popular in Tang Dynasty. These portraits obviously originated from India. Their source images can be found in Buddhist sutras. These portraits of star-gods were used as the idols receive sacrifices. According to the theories of Indian horoscope astrology, offer sacrifices to star-gods can avoid the disasters and dwell on the happiness.

The astronomical materials of Buddhist scriptures in Chinese translation can be divided into five parts:

- Cosmology 
- Naksatras (stars and star groups) system

- Knowledge of Sun and Moon

- Calendar

- Five planets, seven-luminaries and nine-deity

We interpreted these materials in details. The differences and similarities between traditional Chinese astronomy and Indian astronomy that was preserved in the Buddhist scriptures were compared. The influence of Indian astronomy on Chinese astronomy was also expounded.

Finally, the time and the paths by which the Indian astronomy had been introduced into China, together with the distribution area of the Indian astronomy in China, were investigated. Some astronomical knowledge in the Buddhist scriptures was traced to the Babylonian origin. Thereby a picture of astronomy's spreading gradually from the Western to the Eastern was limned. 